\title{
ACADEMIC GOVERNANCE AND LEADERSHIP IN VIETNAM: TRENDS AND CHALLENGES
}

\author{
Jamil Salmi \\ Diego Portales University \\ Ly Thi Pham ${ }^{\text {a }}$ \\ Vietnam National University, Ho Chi Minh City
}

\begin{abstract}
This paper provides a review of academic governance and leadership in Vietnam at both the national and institutional levels, focusing more on the public sector. It also provides an analysis of new policy developments aimed at achieving higher education reform. There have been significant changes over the last three decades regarding governance structures and mechanisms in higher education Vietnam. These changes have been in response to the need for more decentralization and greater consistency with international practices. Increased autonomy for public higher education institutions has been one major achievement. More attention is needed, though, regarding accountability mechanisms. The role of the academic community in higher education leadership also needs to be strengthened by providing more fully for participation by academic staff members in university decision-making process. The privatization of higher education has contributed substantially to higher education development in Vietnam, but the private sector continues to be a focus for ongoing debate because of a perceived need for more improvements.
\end{abstract}

Keywords: Vietnam, governance, higher education reforms, privatization, autonomy, academic freedom

\section{Introduction}

After two decades of rapid expansion, Vietnam's higher education landscape has changed significantly. The numbers of students, institutions and faculty members have increased remarkably, and the emergence of a private sector has been a further aspect of the system's evolution. These changes have contributed greatly to economic growth and social development. Change in the system's governance structures and leadership modes have, however, occurred more slowly, which is presenting some pressing challenges for the system's future.

Appropriate governance has been identified by Salmi (2009) to be of major importance to the effective functioning of higher education institutions (HEIs). This article sets out, therefore, to analyze how governance arrangements and processes have evolved in Vietnam's higher education system over the past two decades. It reviews the structures, processes and activities that are involved in the planning and direction of the system. This task involves looking at system-wide governance and stewardship, as well as examining at an institutional level the governance structures and processes that determine the degree of autonomy that HEls enjoy and the mechanisms of accountability to which they are subject. After providing a description of the Vietnamese higher education landscape, the article explores in succession the main features of system-wide governance, how institutional autonomy has evolved, and the main external factors that explain this evolution.

By way of background, it is of note that Vietnam has been following a course of market-oriented economic reform since the mid-1980s. This reform path has enabled the economy to break free of absolute poverty and to achieve significant and sustained economic growth. Vietnam's GDP per capita

a Correspondence can be directed to: lypham63@gmail.com 
in 2018 was 2,563 US Dollars (USD), and the proportion of its population of 90.7 million living below the national poverty line is rapidly declining. Youth literacy rates are relatively high, compared with most other ASEAN member states, as are net enrolment rates in primary and secondary education. Most Vietnamese (86\%) are ethnically Kinh. There are, however, 53 other ethnic nationalities in Vietnam, most living in the more remote parts of the country (ASEAN, 2018, p.29, p.10).

\section{The National Higher Education Setting}

In 2018, there were $454 \mathrm{HEls}$ in Vietnam, including 95 private universities and colleges, and there were 2.2 million higher education students (MOET, 2019). The latest statistic on the gross enrolment ratio for tertiary education was calculated in 2016, at which time the ratio stood at approximately $28 \%$ of the relevant age group- a vast improvement on the situation in 1993 when the gross enrolment rate was no more than about $2 \%$ (World Bank, 2019).

In school year 2017-2018, there were 74,991 faculty members in all universities and colleges, of whom 20,198 (26.90\%) held a doctoral qualification (MOET, 2019). Faculty members in public $\mathrm{HEIs}$ very often also hold concurrent part-time teaching positions in private HEls. They accept these positions for the purposes of augmenting their relatively low salaries from the public sector - the official monthly salary for faculty members in public HEls ranges between 150 and 500 USD (Viet Nam Government, 2018). No more than a small proportion of faculty members at public HEls engage seriously with research. Many of these institutions label themselves as research universities, but, in fact, their research performance is far from reflecting such an orientation (Pham, 2010; Nguyen \& Pham 2011; Vuong et. al. 2017). The Government also identified criteria for distinguishing between research and teaching HEls, but to date no public university has been officially designated as a research university, including the two national universities. The reasons could be that no institution has yet satisfied the Government's criteria, including that research expenditure should account for at least $20 \%$ of total institutional expenditure per annum, that permanent faculty members have a $50 \%$ workload allocation for research, and that at least $80 \%$ of faculty members are achieving at least one publication annually in a national or international peer reviewed journal (Viet Nam Government, 2015)

Vietnam's higher education system continues to reflect some of the distinctive features of the Soviet model of higher education. One of these is the prevalence of mono-disciplinary HEls (Hayden \& Lam, 2010). Since the mid-1990s, the system has been trying to move away from this model, but it remains the case that very many HEls, especially in the public sector, are narrowly based in terms of the disciplines taught. Examples are the University of Economics and Finance, the University of Fire Fighting and Prevention, and the University of the People's Police. Another feature that reflects the Soviet influence is the separation of research from teaching. In general, universities in Vietnam are focused on teaching. Only a small proportion of universities have much engagement with research. Indeed, by 2016, there were only 59 universities granted permission to conduct doctoral training programs. Recently some private universities have also been permitted to deliver doctoral programs. Research activities generally and $\mathrm{PhD}$ education in particular are still undertaken mainly in research institutes, which are entirely separate from universities. There were 71 of these institutes that in 2015 had permission to offer PhD programs (Pham \& Hayden, 2015, p. 146). These institutes are now officially regarded as forming part of the higher education system (Viet Nam National Congress, 2018).

It is important to note the strong growth in graduate program enrolments over the past decade. Between 2000 to 2008, master-degree enrolments quadrupled to reach 47,000 students by 2008, and PhD enrolments doubled, to reach 5,900 candidates by 2008 (Nguyen \& Nguyen, 2013). Since then, further rapid growth has occurred. By 2016, there were 105,801 master-degree students and $15,112 \mathrm{PhD}$ candidates in Vietnam. 
Another important development over the past two decades has been the emergence of a private higher education sector. These institutions were either 'semi-public', that is, owned by the State but entirely dependent upon tuition fees for their operation, or 'people-founded', that is, established by social organizations and entirely dependent upon tuition fees for their operation (Viet Nam Government, 2000). After 2006, all 'non-public' HEls were expected to become 'fully-private' institutions, with private shareholders and corporate forms of governance. By 2018, there were 95 of these institutions and they accounted for $14 \%$ of all higher education enrolments. Though there continues to be an official expectation that the private sector should grow to account for $40 \%$ of all higher education enrolments by 2020 , this expectation is now impossible to achieve. Over the years, the sector has struggled with a policy environment characterized by delayed decision-making by the Government, which itself has experienced a certain ideological discomfort about the notion of profit- making by private higher education providers (Pham\& Briller, 2015).

\section{System-Level Governance}

There are two dimensions to higher education governance: a system-wide dimension and an institutional dimension (Fielden, 2008). Leadership is a separate matter, referring to a practical skill in being able to achieve compliance in pursuing an individual, team-based or organizational policy direction.

\section{Legislative Bodies and Governance Structure}

As provided for in Article 4 of Vietnam's Constitution, the highest authority in Vietnam is the Central Committee of the Communist Party of Vietnam (referred to hereafter as the Party). Based on its leadership, legislation is developed and implemented by the Government. In 2012, the National Assembly approved for the first time a Higher Education Law (subsequently amended in 2018). Prior to its approval, higher education's legislative foundations rested upon an Education Law, first approved in 1998, and then revised in 2005 and 2009 (and again in 2019). Based on the Higher Education Law, the Government issues decrees for the higher education system, and the Prime Minister and other relevant Ministers issue decisions, circulars and other forms of direction.

As pointed out by Pham\& Hayden, (2015, p. 148), Vietnam does not have a single body responsible for the whole of the higher education and research system. Instead, at least in the public sector, it has a large number of line-management authorities with responsibility for different groups of universities and colleges. The two national universities (which are themselves comprised of multiple specialized universities) are directly managed by the Cabinet; 54 other public universities and colleges are directly managed by Ministry of Education and Training (MOET); another 260 or so public universities and colleges are directly managed by at least 15 other ministries and by over 60 state departments and provincial governments. Private universities and colleges are accountable to MOET regarding academic issues and to local government regarding the appointment of top administrators (Hayden et al. 2012). Management of the system as a whole has become even more complex over recent years following a decision in 2016 to place all two-year colleges under direct line management by the Ministry of Labor, Invalids and Social Affairs (MOLISA). The appointment of the governing boards of public higher education institutions, and of their rectors, is ultimately subject to approval by the relevant line-management authority.

MOET exercises system-wide control of curriculum structures, enrolment quotas and approvals for new academic programs. It is also responsible for the implementation of a national quality assurance system. It is the ministry with the widest range of responsibilities for the higher education system, but its influence is severely constrained by the fact that it is often unable to enforce compliance with its regulations. An example of this situation is that although all HEls are 
required under the "three Disclosures" policy (MOET, 2009) to report publicly on a wide range of performance-related indicators, a sizable proportion of public HEls do not yet do so, as is evident from their websites, and there is no mechanism for holding them to account in this regard.

The Ministry of Science and Technology (MOST) provides research funds and defines research strategies for the public sector of the higher education system. MOST also provides funds in support of the many public research institutes.

As noted earlier, the management authority responsible for two-year colleges is now MOLISA. MOLISA is responsible for vocational training, which is provided by specialized/mono-disciplinary colleges, including 171 colleges (cao dang nghe) and 991 vocational training centres (trung tam day nghe). In addition, there are 301 vocational schools/professional high schools (trung cap nghe/trung hoc chuyen nghiep) that are managed by various ministries or by provincial authorities (Pompa, 2013).

In summary, the governance of the higher education system in Vietnam is highly fragmented. Attempts to remove the line-management role of ministries and other state instrumentalities for public HEls have met with great resistance. Furthermore, some line-management agencies have shown little interest in assisting with the establishment of governing councils within public HEls. Even where they are established, they are regarded as "the fifth wheel of the vehicle" (Lam, 2013a, p.408), that is, unnecessary because of the control already exercised by line-management agencies.

In recent years greater attention has been given to the need for public HEls to having increased institutional autonomy. The amended Higher Education Law dated Nov 19, 2018, and the Regulations on Organizing and Performing of the University of 2014, state that the governing councils of public universities (known as university councils) should have more authority, including the authority to evaluate the rector's performance (Viet Nam Government, 2014). Further movement in this direction would greatly increase the importance of university councils within the public higher education system.

\section{Funding}

By international standards, Vietnam spends heavily on education, but lightly on higher education. More than $18 \%$ of the national budget is allocated by the Government to the education system as a whole (The World Bank, 2013), but in 2013, when the most recent data were available, $15.01 \%$ of public expenditure on the education system was being spent on public HEIs (UNESCO, 2018). This level of expenditure on public higher education is low, having regard to the fact that in a great many countries public expenditure on higher education accounts for more than one-quarter of all public spending on the education system (Chirot \& Wilkinson, 2010, p.56). Public HEls in Vietnam function, therefore, under severe resource constraints.

Funds for public HEls are derived from a range of sources. Ministries and other state instrumentalities with line-management responsibilities for public universities and colleges contribute up to one-half of their operational costs. The Ministry of Planning and Investment (MPI) contributes to their capital costs by providing for campus construction. MOST contributes to their approved research costs. The balance of their funds comes from students and their families in the form of tuition fees.

Tuition fees for public higher education were introduced in 1994, within a framework of 'costsharing' with the Government. For many years, they were set at a very low level. In 2009, public HEls were given permission to increase tuition fee levels, resulting in a steady increase in these levels ever since. By 2015, tuition fees had risen to between 27 and 40 USD per month, depending on the program in which a student enrolled (Pham \& Hayden, 2015). It is also allowed for HEls to charge tuition fees up to 70 USD per month by 2020 (Viet Nam Government, 2015a). To date, as many as 23 self-financed public universities have been approved to set their own rate of tuition fees. In those institutions, tuition fees could be as much as triple the normal rates. The importance of tuition fee income as a proportion of all income received varies remarkably between public HEls and across 
disciplines, ranging from only $20 \%$ in the fine arts, to $26 \%$ in education, to $30 \%$ medicine, and to $56 \%$ economics and law (Dang \& Nguyen, 2014, p.118).

Private HEls rely entirely on tuition fees. There is no limit on the level of the fees they can charge, however the Higher Education Law of 2012 required that $25 \%$ of their profits should be reinvested in their redevelopment. Tuition fees charged by private HEls range from 1,000 to 30,000 USD for full undergraduate degree programs (Viet Nam National Congress, 2012). According to Pham \& Dam (2014), there are four types of private HEIs in Vietnam. First, there are several international universities, RMIT Vietnam and the British University of Vietnam, both of which offer high-fee programs. Second, there are five domestic universities that offer an international curriculum and provide better-than-average facilities for students at their campuses. These institutions also charge high tuition fees. Third, there is a much larger group of institutions that charge tuition fees of between 1,000 and 2,500 USD for their entire programs, and that are, therefore, more likely to be in price competition with public HEls. Fourth, there are niche institutions that charge low tuition fees, of less than 1,000 USD for a complete program and that operate very cheaply. The quality of these institutions is often under a cloud (Hayden \& Dao, 2010; Trines, 2017).

\section{Quality Assurance}

Quality issues have been of great concern to the higher education system in Vietnam over recent years (Nguyen. et al., 2017, p. 159). In 2002, MOET established a new division, the General Directory for Educational Testing and Accreditation (GDETA), to assume responsibility for, among other things, the management of quality assurance across the higher education system. With support from international donors (The World Bank's Higher Education Project 1; and the Dutch Government's ProQuim Project), a pilot external evaluation program with 20 universities involved was conducted in 2008. Based on the results, GDETA then developed a set of criteria for institutional evaluations that have become the official requirement for accreditation (MOET, 2007). It was amended in 2017 based on ASEAN University Network Quality Assurance (AUN-QA) criteria and to be seen closer to international norms. Since then, quality assurance has gained more attention from officials and university administrators, as well as from the general public. Many HEls now have their own quality assurance units (MOET, 2017).

There is, however, no independent quality accreditation agency for the higher education system in Vietnam. The establishment in 2014 of a center for educational accreditation at each of the two national universities may be seen a first step towards creating a capacity for independent quality accreditation. These agencies are providing training for quality assurance auditors, and also a consulting service, thereby promoting quality assurance and supporting its implementation at an institutional level. However, quality accreditation has not become a formal requirement nationwide, and these two agencies function under a licensing arrangement with MOET. MOET also controls the issuing of certificates to quality auditors (Nguyen et al., 2017, p. 156). There is now an Education Quality Management Agency within the Ministry, which has responsibility for managing five centres for higher education accreditation, including one with specific responsibility for auditing self-assessment reports produced by private higher education institutions.

\section{Institutional Governance and Leadership}

\section{Public HEls Governance and Leadership}

Since 1975, public HEls in Vietnam have been governed according to a centralized model in which decision-making authority at the institutional level has been almost entirely controlled by the State (Dang \& Nguyen, 2014, p.106). The exceptions were the two national universities (one established 1993 in Ha Noi and the other established in 1997 in Ho Chi Minh City), which were permitted to have 
more autonomy because they were held accountable to the Prime Minister and Cabinet, and the fact that they were funded by the Ministry of Finance (MOF) and the Ministry of Planning and Investment (MPI). Even for these universities, however, MOET initially controlled matters relating to enrolment quotas, tuition fees rates, programs and curriculum frameworks (Viet Nam Government, 2001).

Recent reforms in the Vietnamese economy have been accompanied by a shift in higher education governance towards increased levels of autonomy for public HEls (Hayden \& Lam, 2017). The concept of a university council was introduced for the first time in the University Charter in 2003, then again in the 2005 Education Law, and became more specific in the amendments to the University Charter in 2010 and 2014. The Higher Education Law of 2012 declared that each public $\mathrm{HEl}$ should have a governance body with membership that included the rector and vice-rectors, the Party Secretary, a labor union representative, elected faculty representatives and representatives of line-management agencies (for example, MOET, line-ministries, or provincial People Committees, and so on). Membership was also to include people from industry and the professions - to comprise at least $20 \%$ of the total members). The president of a university council was to be appointed by the state then elected by its members and recognized by the state (Viet Nam Goverment, 2014; Viet Nam National Congress, 2018; 2012). The rector was required to recommend a list of university council members to the relevant line-management body for approval and the issuing of recognition decisions (Viet Nam Government, 2014).

By law, a university council is now responsible for approving the institutional charter, the strategic development plan and the organizational structures, as well as for supervising the implementation of the strategic plan (Article 16 of Higher Education Law 2012, and as amended in 2018). Even though a university council is designated as representing the owner of the institution, the most important decision-the appointment of the rector-remains with the relevant linemanagement authority, whether MOET, other ministries, or provincial authorities in the case of local/private HEls (Viet Nam Government, 2014). That the Amended Higher Education Law of 2018 delegated the power to make this decision to the university council may be seen as a significant change, but in practice government authorities continue to play a critical role because they must give recognition to decisions in this regard by university councils (Viet Nam National Congress, 2018).

Within public universities, therefore, the authority of university councils is weak. University administrators have tended to regard university councils as no more than a form of window dressing (Lam, 2013a, p. 408). That is why public universities have generally been very slow in establishing university councils. Between 2003 and 2010, for example, only 10 public universities had established a university council. However, in February 2015, MOET announced that all the public HEls should have established a university council.

In theory, the university council is a structure aimed at separating the oversight and execution parts of university management, seeking to ensure a balance between institutional autonomy and accountability. However, in the transition from a centralized economy to a socialist-oriented market economy, university councils have been caught in the power struggle between line-ministries and Party cells, which have sought to maintain an institutional leadership role within universities. A common practice to emerge has been to combine the roles of the university council and of the rectorate board (comprised of the rector and vice-rectors), thereby undermining the functions of a university council as the institutional governing body. The latest legislation, University Charter 2014, and the Amendment of Higher Education Law 2018, requires that rectors and vice-rectors should not act as chairs of university councils, but in practice there is considerable overlap between the roles performed by university councils and rectorate boards. A contributing factor is that university employees still tend to dominate the membership of university councils. That is why the Amendment of Higher Education Law 2018 has requested that the number of members outside the university must be at least $30 \%$ of the total university council members, and faculty member representatives must be accounted for $25 \%$ of the total (Viet Nam Government, 2014; Viet Nam National Congress, 2018). 
Decision-making processes within public HEls remain hierarchical and top-down. There is a lack of effective mechanisms to ensure a diversity of stakeholder perspectives, such as might be provided by employers, academics and students. Scientific councils (Hoi dong Khoa hoc), or academic boards (Hoi dong Dao tao), serve as advisory bodies, not as decision-making bodies. Within each institution, the Party cell continues to play an important role in determining personnel appointments at the top levels, even though, officially, the Party cell does not have a formal role. Generally speaking, there is little room for university leaders in public HEls to exercise leadership in an autonomous fashion. They serve the institution as administrators or managers.

At the same time, there is a dearth of effective accountability mechanisms (Hoang, 2017; Lam 2018). Of 21,502 words of the University Charter of 2014, only 110 words referred to the issue of accountability. The main accountability responsibility is to comply with MOET regulations. As one expert recently commented, "the decision-making power of the rector at the institutional level is stronger than in any other institution across the world" (Lam, 2013a, p. 408). As long as the rector adheres to MOET instructions, or to the instructions given by other relevant line-management authorities, he or she can make decisions with little regard to the wishes of other stakeholders. Aware of this shortcoming, MOET now requests that all HEls should disclose publicly on a website details regarding their infrastructure, staffing and finance. Few public universities fully comply with these requirements, however, and MOET appears limited in terms of its capacity to force compliance.

In general, there is a quid pro quo relationship between rectors of public universities and their line-management authorities. Provided the rectors adhere to specific instructions considered by their line-management authority to be important, they are left to manage their institutions without much constraint.

\section{Private HEls Governance and Leadership}

Institutional governance and leadership structures in private HEls are regulated by the State. The development of governance and leadership mechanisms for private institutions has undergone two decades of evolution since 1993. Non-public HEls, when first sanctioned in 1993, were either 'semi-public' or 'people-founded' institutions (Communist Party of Viet Nam, 1993). Their decisionmaking bodies were similar to their public counterparts. Over time, and particularly since 2005, their governance structures have shifted towards a fully corporate model. In 2006, and subsequently, the Government has preferred to refer to them as 'fully-private' institutions, accountable to their shareholders through an annual shareholder meeting. The shareholders were given responsibility for appointing the governing boards of these institutions, and the governing boards then for appointing electing rectors (subject to approval by provincial authorities).

Compared with public HEls, private HEls have more financial autonomy and more control over the appointment of all faculty members, including rectors and vice-rectors. Private HEls also have more freedom in terms of developing institutional policies and procedures, approving salary determinations and academic promotions, and for the establishment of relationships with stakeholders. As in the case with public HEls, however, they must attend to MOET's regulations regarding curriculum structures and content, assessment requirements and conditions for the granting of degrees. Many private HEls generally appear to mimic the public HEls rather than take advantage of the greater freedom available to them to decide various matters independently. Similarities between the public and private sectors of higher education in Vietnam are, therefore, more pronounced than the differences.

In general, concepts of institutional autonomy and institutional accountability are not well understood within Vietnam's higher education system. Institutional autonomy is often regarded as referring only to autonomy in the management of resources (Dao \& Hayden, 2012, p. 135). Both public and private HEls have limited freedom to make decisions in academic matters. In Vietnam, accountability has mostly been translated into Vietnamese as 'tu chiu trach nhiem' (selfresponsibility) or 'trach nhiem xa hoi' (social responsibility). It has taken more than a decade for the 
word "accountability" to be translated into Vietnamese correctly as 'trach nhiem giai trinh' (Pham, 2012a, p. 57), though this translation continues often to be overlooked. This latest term is finally being used in the most recent legislation document in higher education, that is, the Amendment of the Higher Education Law 2018.

In terms of institutional autonomy, the three important decision-making entities are the governing council (or board in the case of private HEls), the Party cell and the rector. For public HEls, the power of the governing council is weak, as noted earlier. In private HEls, the governing board is a more powerful body because it can recommend the appointment or dismissal of a rector. Before 2014, in both public and private HEls, however, there was no restriction on individuals concurrently holding positions as rector, member chair of the governing board, and officials within secretary of the Party cell. Rectors' executives often perform, therefore, without proper supervision. Although they must abide by MOET's regulations on academic matters, they remain well able to exercise considerable personal power in terms of resource allocation and personnel decisions.

\section{Leadership by the Academic Community}

A traditional aspect of leadership in universities is the importance of the role played by academic leaders, especially by the professoriate, in maintaining academic standards and in developing research and training programs as the core business of the university. Almost all Vietnamese public universities allow for the existence of an academic council (Hoi dong Khoa hoc va Dao tao) in their organizational structures. This body is established by the rector to serve in an advisory capacity on academic matters. Article 19 of the Higher Education Law of 2012 provides guidance about the role of this council, stating, for example, that it should: develop regulations on research and training activities; develop employment criteria for faculty members; make plans for staff development; recommend on the establishment or removal of academic programs; develop research plans; and develop plans for the assignment of academic workloads (Viet Nam National Congress, 2012).

The membership of the council normally includes the rector, the vice-rectors in charge of training and research, heads of relevant divisions, some faculty deans, and faculty representatives who are members of the professoriate or have doctoral qualifications. Academic councils may also include respected scientists and scholars in scholarly fields related to the work of the university, even though these persons may not be employees of the institution concerned. The president of an academic council is usually elected by the council, and resolutions passed by an academic council are considered to be valid when agreed by more than $50 \%$ of the members of a meeting at which more than two-thirds of all members are present (Viet Nam Government, 2014, Article 13).

Notwithstanding the scope provided by the Higher Education Law of 2012 for academic councils to exert leadership across a wide range of academic matters, most of their influence tends to be confined to screening research proposals and to providing recommendations on the allocation of the university research funds. Their capacity to exert a wider influence is constrained by the fact that MOET's prescriptions regarding academic programs leave little scope for maneuver. In addition, academic councils are not decision-making bodies, and they cannot act independently of the university leadership. Indeed, their authority is so limited that it is rare for there to be any tension between academic councils and rectors. Many private HEls don't bother to establish an academic council (Pham, 2017).

At the departmental level, the role of the Dean and scientific councils appears generally to be more effective (Nguyen \& Meek, 2016, p. 61). Faculty members at a departmental level share academic interests in common, which motivates them to participate more fully in decision-making processes. 


\section{Local, Regional and Global Drivers}

Vietnam's higher education system over the past two decades has been dominated by a need to expand for the purpose of satisfying the aspirations of a nation with a strong appetite for more educational opportunities. The system has made remarkable progress in this regard, but its progress in terms of quality improvement is much less evident. Among the various reasons why the quality of the system has been slow to improve is a failure to develop an effective and appropriate governance and leadership model for the system. This matter is now addressed.

\section{The Evolution of University Autonomy and Academic Freedom}

As noted above, line-management control of public HEls by ministries and other state instrumentalities remains a distinctive feature of the current governance and leadership model for the higher education system. The State provides a little over $50 \%$ of the total revenue of the public HEls (Nguyen et al. 2012, p. 258), but it maintains relatively tight control on most of the important decisions affecting the system. Public HEls have been permitted to keep earnings from the provision of 'non-formal' teaching programs, for which they may set the tuition fees at whatever level they consider the market can bear, and this income has provided institutional leaders with more autonomy in terms of being able to pay teaching staff, fund capital improvements and develop infrastructure, such as library support. Indeed, these 'non-formal' programs are being seen as the 'rice-cookers' of the public HEls. That is, they have become a vital source of support for the public higher education system, helping to ensure its viability. The problem, though, is that these programs are undermining the academic standards of public universities because they function on the basis of there being less stringent admission requirements and conditions of teaching and learning that would be unacceptable for the 'regular' programs (Chirot \& Wilkinson, 2010; Lam, 2013b).

There were few other opportunities for public HEls to exercise institutional autonomy regarding matters of significance to academic life. The curriculum frameworks issued by MOET are highly prescriptive. Though individual HEls may vary content up to a certain percentage within an academic program, they are not permitted to restructure academic programs, nor are they permitted to introduce new academic programs without obtaining permission from MOET. Not surprisingly, therefore, curriculum renewal was extremely slow- moving. However, the Amendment of Higher Education Law 2018 states that HEls which meet certain requirements for institutional autonomy and for criteria of particular programs are permitted to establish them (Viet Nam National Congress, 2018).

In general, there is a view from high levels within the higher education system, including government high ranked officials and some senior scholars, that institutional autonomy should be bestowed upon public HEls as a favor rather than a right exercised by national and global centers of advanced learning. The Higher Education Law of 2012 and the Amendment in 2018 present the promise of more institutional autonomy for public HEls, but its extent is made conditional on institutional capabilities and the results of rankings/accreditation. Furthermore, it is viewed from a perspective of making selected public HEls more financially autonomous so that they can relieve the financial burden on the State. To date, 23 public HEls have been granted far greater levels of institutional autonomy by a mechanism entitled "self-financed". They have been permitted to increase their tuition fee levels well beyond the ceiling set for tuition fees in the public sector, and they are being expected to manage their own expenditure, with no funds available from the State (Viet Nam Government, 2014a).

In fairness, public HEls have not in the past made as much use of the levels of autonomy that have been given to them by the State. Decree 46/ND-CP, for example, explicitly permitted rectors of public HEls to pay higher salaries to faculty members (up to 2.5 times greater than is prescribed in the public service compensation scheme), but none of them ever elected to exercise this right (Pham, 2012, p.305; Viet Nam Government, 2006). They might aware of these possibilities but 
the payment level still remained modest due to their institutional limited incomes, or due to the priorities they set for expenses.

Academic freedom remains a sensitive issue in Vietnam's higher education system. Compared with the 1980s or 1990s, however, far greater openness is now evident, as may be seen from the extent to which English language institutes now operate all over Vietnam and two foreign-owned universities are free to teach programs in ways that are familiar to them in their home countries. There has also been a mushrooming of international partnership programs. Self-censorship remains widespread, but the interaction with the global world is making limitations on academic freedom less meaningful and less effective.

\section{Privatization and Emergence of the Private Sector}

Vietnam has followed the path of most other East Asian countries by allowing a private higher education sector to develop as an integral part of the national higher education system (Levy, 2010). As reported earlier, Vietnam sanctioned the first idea for establishment of the 'non-public' higher education institutions in 1993. The popularity of these institutions during the early 2000 s came possibly as a surprise, but there were also instances of corrupt practices. The growth of the sector was then contained up until 2005-06, when a private 'for-profit' sector became fully recognized. Since then, the Government has expressed highly ambitious goals for the sector, expecting, for example, that it might account for $40 \%$ of all higher education enrolments by 2020 (Hayden \& Dao, 2010, p. 215). It has, at the same time, done little to support the development of the sector, leaving it to survive and grow as best it can. The sector appears now to have stopped growing in terms of quantity, and the prospect of it ever accounting for $40 \%$ of all higher education enrolments seems to have become remote.

\section{Internationalization and the Blossoming of Partnership Programs}

Integration with the global economy requires Vietnam to have higher quality higher education system to strengthen its global competitiveness. Employers in Vietnam currently complain about graduates lacking communication skills, teamwork and problem-solving capabilities. As pointed out in a World Bank report (2014, p. 18), Vietnam's skill development system today is not as responsive as it needs to be and is suffering from disconnects among employers, students, and universities. $\mathrm{HEls}$ are offering programs and producing graduates with skills that do not fully reflect the needs of the labor market.

Reforms aimed at more effective governance and better leadership performance in the Vietnamese higher education system have been slow-moving. As a result, curriculum and teaching methodologies have changed little over the years and there is a low level of trust in the quality of domestic programs. This situation explains the mushrooming of international partnership programs, delivered in various forms, including 2+2 (two years in Vietnam, and another two years in an international partnership institution), or three years in Vietnam plus one year abroad, or one year in Vietnam plus one year abroad for master-degree programs. It is reported that by 2016 there were as many as 475 academic programs from across the system that involved foreign partners.

These programs add a new style of teaching and learning to the higher education system in Vietnam. They bring a new environment for students and they expose them to higher education programs in a global world setting. They also contribute to fluency in English or other foreign languages. However, the extent to which the academic standards of the international partners are maintained remains an unanswered question because the increasing need perceived by young people to have a 'foreign degree' has also generated a 'foreign degree market', which attracts poor quality partnership programs as well as many that are quite sound. 
RMIT-Vietnam can be seen as a success case in terms of establishing an international environment for Vietnamese students. It meets the needs of a growing middle-class wishing to have a better education for its young people but not yet able to afford the expense of studying abroad. RMIT-Vietnam was established as a foreign business under a license of the MPI. It has made a positive impact on the higher education system by providing alternative options and stimulating the internationalization of domestic institutions (Pham, 2014).

An important consequence of internationalization is increased recognition of the importance of quality assurance and accreditation, as can be seen in the cases of three leading HEls in Vietnam: the Vietnam National University in Hanoi (VNU-HN), the Vietnam National University in Ho Chi Minh City (VNU-HCMC), and Can Tho University (CTU). The two national universities joined the ASEAN University Network (AUN) in 1999, and CTU joined the Network in 2013. These achievements are important for the higher education system more broadly because they serve notice to all universities and colleges that an alignment with international norms and standards is essential for the development of quality and the attainment of regional recognition.

\section{Rankings}

Rankings of universities are now a global phenomenon. As has happened elsewhere in Southeast Asia, Vietnam has set its sights on having a number of universities recognized as being 'world-class'. In typical fashion, the Government has ambitiously declared that at least one public university should be recognized 'world-class' by 2020. There has been debate, however, about the appropriate strategy for achieving this outcome. In particular, is it better to reform and upgrade existing universities, or to establish new ones? The Government has decided to follow both strategies. Since 2008, it has been pursuing the development of three 'new model' universities, one in collaboration with Germany, one in collaboration with France, and one in collaboration with Japan. Special governance arrangements, including high levels of institutional autonomy, innovative curricula and contemporary global personnel management practices, are being permitted at these institutions. Some of those institutions were funded by the World Bank under a project aimed at developing an autonomous research-based university to demonstrate a new policy framework on governance, financing, and quality in Vietnam's higher education system. To date, however, the success of these projects has been modest (World Bank, 2017). Meanwhile, as noted earlier, the Government has granted 23 universities far greater levels of financial autonomy. This is the case, in particular, for the two national universities and some public self-financed institutions such as the Foreign Trade University in Hanoi and Ton Duc Thang University.

The Higher Education Law of 2012 introduced the notion of a national ranking system for HEls in Vietnam as a basis for awarding privileges, including priority funding and increased institutional autonomy. The Law stated that: "Based on rankings results, government authorities decide investment planning priorities, delegating responsibilities and special regulating mechanisms (...). Based on rankings results, MOET in conjunction with local government support private HEIs by land use, capital loan, and human resource development" (Viet Nam National Congress 2012, Article 9). Ranks were to be determined on the basis of criteria that included: the position and role of the institution within the system; the number of programs and level of degrees granted; the structure and development of research activities; scientific performance and outputs; and accreditation results. The process for implementing this national ranking system has, to date, been slow- moving. The 73/2015-ND-CP Decree on stratification and rankings has not brought about any noticeable change in reality. Most recently, the Amended HE Law of 2018 has indicated that ranking results will not be regarded as a basis for resource allocation decisions (Viet Nam National Congress, 2018). The logic behind this decision could be that such a policy might trigger unhealthy approaches to achieving high ranks. 


\section{Conclusion}

Transforming the higher education system in Vietnam is an ongoing process. Vietnam's need to integrate with the global economy has placed it under significant pressure to improve the quality of its higher education system, and hence the quality of the governance and leadership of the system. As Dao and Hayden (2012, p. 129) pointed out, however, how the higher education system is governed and led needs to be seen in the context of how Vietnam itself is governed and led. Vietnam's political system retains many aspects of the top-down management style that was characteristic of the Soviet period of influence, and views on how the public higher education system should be managed will inevitably be influenced by this tradition.

Several factors have influenced its transformation, not just the political setting. First, the quality of higher education directly affects economic growth, the national competitiveness, and therefore the stability of the nation. Second, the constraints of public resources have stimulated the development of private higher education and increased cost sharing in public HEls. Third, as a consequence, the open-door policy in the economy has led to increased participation of the private sector and international businesses, including in the higher education arena. This gives people more choices and alternative paths. Public HEls are no longer the only source of knowledge and degrees needed for the labor market. Finally, the advance of communication technology facilitates the interactions between Vietnam's HEls and their international counterparts, and between the Vietnamese academic community and their international colleagues.

Government initiatives also play a key role in this process, through the programs aimed at strengthening the quality of faculty staff members, such as the 911 Project (to produce 20,000 PhD holders at home and abroad, by 2020). More and more people who have been trained abroad are returning to Vietnam and taking important positions within the system. The current governing model in Vietnam's higher education system, at both national and institutional levels, seems too restrictive in a rapidly changing system. The pressure to reform is therefore strong, but resistance is also strong among those rectors who take advantage of the quid pro quo system that allows the power holders to protect their independence at the expense of improving quality.

The three decades of revolution in the transformation of the governance and leadership model since Doi Moi have witnessed a trend towards greater autonomy and openness, less state control and more marketization. This trend is consistent with the corporatization of the governing model that has taken place in public HEls in countries such as Singapore or Japan.

The evolution towards the development of private higher education and the marketization of higher education will certainly bring about further governance reforms in the direction of greater institutional autonomy and strengthened accountability. The consolidation of quality assurance and accreditation bodies will allow them to play a more active role as professional organizations. This will help unleash the potential of Vietnam's higher education so that it can contribute better to the development of the country. The process is slow, but irreversible. 


\section{References}

ASEAN Secretariat (2018). ASEAN Key Figures 2018. Available at https://asean.org/storage/2018/12/ ASEAN-Key-Figures-2018.pdf [Accessed 15 Sept 2019].

Chirot, L. and Wilkinson, B. (2010). The Intangibles of Excellence: Governance and the Quest to Build a Vietnamese Apex Research University. Available at https://ash.harvard.edu/links/ intangibles-excellence-governance-and-quest-build-vietnamese-apex-research-university [Accessed 10 August 2019].

Communist Party of Viet Nam (1993) Resolution 4-NQ/HNTW Term VII: Regarding Work on the Youth in New Stage. Available at http://tulieuvankien.dangcongsan.vn/van-kien-tu-lieu-ve-dang/ hoi-nghi-bch-trung-uong/khoa-vii/nghi-quyet-so-04-nqhntw-cua-hoi-nghi-lan-thu-tu-bchtwdang-khoa-vii-ve-cong-tac-thanh-nien-trong-thoi-ky-moi-ngay-14011993-1125 (In Vietnamese) [Accessed 15 Sept 2019].

Dang, Q.A. and Nguyen, D.C. (2014). Governance in Vietnam Higher Education. Leadership and Governance in Higher Education, 4, pp.95- 125.

Fielden, J. (2008). Global Trends in University Governance. Available at http://siteresources. worldbank.org/EDUCATION/Resources/278200-1099079877269/547664-1099079956815/ Global_Trends_University_Governance_webversion.pdf [Accessed 15 Sept 2019].

Goyette, K. A. (2012). Stratification and the emergence of the postsecondary private education sector in Vietnam. Comparative Education Review, 56(2), pp.197-222.

Hayden, M. and Lam, Q.T. (2007). Institutional autonomy for higher education in Vietnam. Higher Education Research \& Development, 26(1), pp. 73-85.

Hayden, M. and Lam, Q.T. (2010). Vietnam's higher education system. In G. Harman, M. Hayden \& T.N. Pham (Eds.) Reforming Higher Education in Vietnam. Dordrecht: Springer, pp. 14-29.

Hayden M. and Pham, T.L. (2015). Higher education access and inclusion: Lessons from Vietnam. In C. Yeakey, R.T. Teranishi, W. R. Allen, L.B. Pazich \& M. Knobel, M. (Eds) Mitigating Inequality: Higher Education Research, Policy, and Practice in an Era of Massification and Stratification. Bingley: Emerald Group Publishing Limited, pp. 19-33.

Hayden, M. and Van Khanh, D., (2010). Private higher education in Vietnam. In G. Harman, M. Hayden \& T.N. Pham (Eds.) Reforming Higher Education in Vietnam Dordrecht: Springer, pp. 215-225

Hoang, L. (2017). Accountability in Vietnam's Education: Toward Effective Mechanism in the Decentralization Context. Available at https://unesdoc.unesco.org/ark:/48223/pf0000259548 [Accessed 15 Sept 2019].

Hoang, L. (2018). Twin Privatization in Vietnam Higher Education: The Emergence of Private Higher Education and Partial Privatization of Public Universities. Higher Education Policy, 32(3) pp.359380.

Lam, Q.T. (2013a). Some Issues about Board of Governance in Vietnamese Public Universities (In Vietnamese: Một số vấn đề về Hội đồng Trường trong các trường ĐH công lập ở Việt Nam). In Nguyen Thi My Loc, Nguyen Huu Chau (Eds) Vietnamese Higher Education, The Issues of Quality and Management (In Vietnamese: Giao duc Dai hoc Vietnam: Nhung van de chat luong va quan (y). Hanoi: Vietnam National University Ha Noi Press, pp. 408-420.

Lam, Q.T. (2018). Ensuring university autonomy and accountability (In Vietnamese: Đảm bảo quyền tự chủ và trách nhiệm giải trình của các trường $Đ H^{\prime \prime}$. Paper presented at the Association of Science and Technology Conference, Ha Noi, Vietnam, 21 October 2018.

Levy, D. C. (2010). East Asian private higher education: Reality and Policy. New York: University at Albany-SUNY.

MOET (2007). Decision 65/2007/BGD-DT: The Regulations on Assessment Criteria for Higher Education Institutions. Available at http://vanban.chinhphu.vn/portal/page/portal/chinhphu/ hethongvanban?class_id=1\&_page=111\&mode=detail\&document_id=45736 (In Vietnamese). [Accessed 15 Sept 2019]. 
MOET (2009). Circular 09/2009/BGD-DT: The Regulations on Transparency in Education Institutions. Available at https://thuvienphapluat.vn/van-ban/Giao-duc/Thong-tu-09-2009-TT-BGDDTquy-che-cong-khai-co-so-giao-duc-he-thong-giao-duc-quoc-dan-89997.aspx (In Vietnamese). [Accessed 15 Sept 2019].

MOET (2017).Circular 12/2017/BGD-DT: The Regulations on Accreditation of Higher Education Institutions Available at http://vanban.chinhphu.vn/portal/page/portal/chinhphu/ hethongvanban?class_id=1\&_page=1\&mode=detail\&document_id=99977 (In Vietnamese). [Accessed 15 Sept 2019].

MOET (2019). Higher Education Statistic Data. Available at http://www.moet.gov.vn/thong-ke/Pages/ thong-ko-giao-duc-dai-hoc.aspx?ltemID=5877 and http://www.moet.gov.vn/thong-ke/Pages/ thong-ko-giao-duc-dai-hoc.aspx?ItemID=5878 [Accessed 15 Sept 2019].

Nguyen, N.A (2012). State funding allocation in Public HEls: The current Situation and Recommendations. (In Vietnamese: Co che phan bo ngan sach cho DH cong lap, hien trang va khuyen nghi). Paper presented at the Conference on Finance Reforms to Higher Education in Vietnam, Ha Naoi Vietnam, 17 November 2012.

Nguyen, T.L.H. and Meek, V. L. (2016). Key Problems in Organizing and Structuring University Research in Vietnam: The Lack of an Effective Research "Behaviour Formalization" System. Minerva, 54(1), pp. 45-73.

Nguyen, T.M.L. and Nguyen H.C (2013). Vietnamese Higher Education: The Issues of Quality and Management (In Vietnamese: Giao duc Dai hoc Vietnam: Nhung van de chat luong va quan ly). Ha Noi: Vietnam National University Ha Noi Press.

Nguyen, V.T. and Pham, T.L. (2011). Scientific output and its relationship to knowledge economy: an analysis of ASEAN countries. Scientometrics, 89(1), pp. 107-117.

Nguyen, H. C., Ta, T. T. H., and Nguyen, T. T. H. (2017). Achievements and lessons learned from Vietnam's higher education quality assurance system after a decade of establishment. International Journal of Higher Education, 6(2), pp.153-161.

Pham, D.H. (2010). A comparative study of research capabilities of East Asian countries and implications for Vietnam. Higher Education, 60(6), pp. 615-625.

Pham, H.H. (2011). Vietnam: Higher Education Quality Poor, Says Minister. Available at http://www. universityworldnews.com/article.php?story=2011120222340338. [Accessed 15 Sept 2019].

Pham, P. (2012). A New Face of Vietnamese Higher Education. (In Vietnamese: Về khuôn mặt mới của giáo dục ĐH Việt Nam). Vietnam National University HCM Press.

Pham, T.L. (2012a). University autonomy and accountability: The relationships between state, university and the society. Science and Technology Development Journal 15(1), pp.57-66.

Pham, T.L. (2014). Managing the expansion and quality: The role of private sector and international participation. Paper presented at Expanding Tertiary Education Out and Up to Stimulate Economic and Social Development: An Emerging Research Agenda for Asia and the Pacific, Langkawi, Malaysia 13-14 November, 2014.

Pham, T.L. (2017). The Role of Academic Council in Vietnam Universities (In Vietnamese: Vai trò của Hội đồng Khoa học trong các trường ĐH Việt Nam). HUFLIT Journal of Science, 4, pp.25-32.

Pham, T.L. and Briller, V. (2015) Private Higher Education in Vietnam and Recent Policy Development. Conference Proceedings by Vietnam National University Ha Noi. (In Vietnamese: Những bước phát triển mới trong chính sách đối với Giáo dục Đại học tư ở Việt Nam). Available at https:// www.lypham.net/?p=1285 [Accessed 15 Sept 2019].

Pham, T.L. and Dam, Q.M. (2014). Non-public Higher Education in Vietnam: Policy Uncorking is Needed. (In Vietnamese: Giáo dục ĐH ngoài công lập ở Việt Nam, những nút thắt cần tháo gỡ. Báo Tuổi trẻ Cuối tuần). Available at https://www.lypham.net/?p=1083 [Accessed 15 Sept 2019]. 
Pham, T.L. and Hayden, M. (2015). Vietnam's higher education system in transition: the struggle to achieve potential. In R. Bhandari \& A. Lefébure (Eds.) Asia: The Next Higher Education Superpower? New York: Institute of International Education, pp. 145-160.

Pompa, C. (2013). Business Engagement to Promote Quality Vocational Training in Vietnam. Available at https://www. odi. org/sites/odi. org. uk/files/odiassets/publications-opinion-files/8960. pdf. [Accessed 10 August 2019].

Salmi, J. (2009). The Challenge of Establishing World-Class Universities. Washington DC: The World Bank.

Trines S. (2017). Education in Vietnam. Available at https://wenr.wes.org/2017/11/education-invietnam [Accessed 15 Sept 2019].

Viet Nam Government (2000). Decision 86/QD-TTg: The Regulations on People-Founded University. Available at https://thuvienphapluat.vn/van-ban/giao-duc/quyet-dinh-86-2000-qd-ttg-quyche-truong-dai-hoc-dan-lap-46535.aspx (In Vietnamese). [Accessed 15 Sept 2019].

Viet Nam Government (2001). Decision 16/2001/QD-TTg: The Regulations on Organizing and Operations of the National Universities Available at http://www.chinhphu.vn/portal/page/ portal/chinhphu/hethongvanban?class_id=1\&_page=549\&mode=detail\&document_id=8572 (In Vietnamese). [Accessed 15 Sept 2019].

Viet Nam Government (2006). Decree 43/2006/ND-CP: Regulations on Institutional Autonomy and Self-Responsibility of Public Agencies. Available at: http://vanban.chinhphu.vn/portal/page/ portal/chinhphu/hethongvanban?class_id=1\&_page=1\&mode=detail\&document_id=15218(In Vietnamese) [Accessed 15 Sept 2019].

Viet Nam Government (2014). Decision 70/2014/QD-TTg: Issuing the University Charter. Available at http://www.chinhphu.vn/portal/page/portal/chinhphu/hethongvanban?class_ id=1\&mode=detail\&document_id=177916. ). (In Vietnamese) [Accessed 15 Sept 2019].

Viet Nam Government (2014a). Resolution 77/NQ-CP dated 24 Oct 2014: Piloting the Operational Mechanisms of the Public Higher Education Institution in the stages of 2014-2017. Available at http://chinhphu.vn/portal/page/portal/chinhphu/hethongvanban?class_ $i d=509 \&$ mode $=$ detail\&document_id=177020. (In Vietnamese) [Accessed 15 Sept 2019].

Viet Nam Government (2015). Decree 73/2015/ND-CP: Guidance for Criteria of Classification and Rankings of Higher Education Institutions. Available at http://vanban.chinhphu.vn/portal/ page/portal/chinhphu/hethongvanban?class_id=1\&mode=detail\&document_id=181353 (In Vietnamese). [Accessed 15 Sept 2019].

Viet Nam Government (2015a). Decree 86/2015/ND-CP: The Regulations on Tuition Fees in Public Education Institutions. Available at http://vanban.chinhphu.vn/portal/page/portal/chinhphu/ hethongvanban?class_id=1\&_page=1\&mode=detail\&document_id=181665 (In Vietnamese). [Accessed 15 Sept 2019].

Viet Nam Government (2018).Decree 72/2018/ND-CP: The Regulations on Basic Salaries for Government Officers, Staffs and Military Personnel. Available at http://vanban.chinhphu.vn/ portal/page/portal/chinhphu/hethongvanban?class_id=1\&_page=1\&mode=detail\&document_ $\mathrm{id}=193753$ (In Vietnamese). [Accessed 15 Sept 2019].

Viet Nam National Congress (2012). Law No. 08/2012/QH13: Issuing Higher Education Law. Available at http://www.chinhphu.vn/portal/page/portal/chinhphu/ hethongvanban?mode=detail\&document_id=163054 In Vietnamese). [Accessed 15 Sept 2019].

Viet Nam National Congress (2018). Amended HE Law 2018: Law No 14/2018/QH14 on Amendment of Some Articles in Higher Education Law. Available at https://thuvienphapluat.vn/van-ban/ giao-duc/Luat-Giao-duc-dai-hoc-sua-doi-388254.aspx (In Vietnamese). [Accessed 15 Sept 2019]. 
Vuong, Q. H., Ho, T., Vuong, T. T., Napier, N. K., Pham, H. H. and Nguyen, H. (2017). Gender, age, research experience, leading role and academic productivity of Vietnamese researchers in the social sciences and humanities: exploring a 2008-2017 Scopus dataset. European Science Editing, 43(3), pp. 51-55. World Bank (2014). Skilling up Vietnam: preparing the workforce for a modern market economy. Washington, DC: World Bank Group.

World Bank. (2017). Vietnam - New Model University Project: Restructuring (English). Washington, D.C.: World Bank Group.

World Bank. (2019). World Bank Development Indicators. Available at https://data.worldbank.org/ indicator/se.ter.enrr [Accessed 15 Sept 2019]. 